\title{
Олег Перепелиця
}

\section{РЕВІЗІОНІСТСЬКО-КОНТЕКСТУАЛЬНА РЕКОНСТРУКЦІЯ ФІЛОСОФСЬКОЇ «СИСТЕМИ» МАРКІЗА ДЕ САДА.}

\section{Lloyd, H.M. (2018) Sade's Philosophical System in its Enlightenment Context. Saint Lucia: Springer International Publishing; Palgrave Macmillan.}

У червні 2020 року світова інтелектуальна еліта святкує ювілей з дня народження, можливо, найконтраверсійнішої особистості в історії філософії і літератури, просвітницької думки й модерної уяви - Донасьєна Альфонса Франсуа де Сада (1740-1814). Звісно, навряд чи ми побачимо пишні святкування з промовами офіційних державних осіб, хай яким класиком уже не вважається Сад. Проте його постать не буде обійдена увагою в академічному середовищі публікою, ані в «жовтих» медіа. Книга австралійського філософа з університету Квінсленда, фахівця з історії французької, зокрема просвітницької, філософії Генрі Мартина Лойда «Філософська система Сада в її просвітницькому контексті» поповнює вже доволі потужну традицію тлумачень Сада оригінальною (ре)презентацією його філософії саме в контексті Просвітництва. Звісно, це далеко не перша академічна спроба визначити місце Сада у філософії Просвітництва (і в тому, що називають «діалектикою Просвітництва») й окреслити дивовижну актуальність Садових філософських чи світоглядних прозрінь ${ }^{1}$.

Щоправда, Лойд відзначає переважно легковажний статус Сада в англомовній філософській традиції, що пов'язано й із рівнем перекладів, i, певною мірою, із упередженим ставленням до французької філософії. Це доволі цікаво й навіть симптоматично для нас також, бо в українському контексті Сад - це загалом маргіналія, якій майже не приділяють уваги, чи то соромлячись, чи то побоюючись. Нагадаю, що досі існує лише один, нехай і добрий, переклад чи не найрозважливішої книги Сада - «Філософії в будуарі», - зроблений Андрієм Рєпою [Сад 2016]. Тож українському читачеві, мабуть, ще складніше усвідомити ту «серйозність» (р. х $)^{2}$, із якою ставляться до Сада французькі інтелектуали ${ }^{3}$.

Підхід самого Лойда до читання Сада поєднує дві традиції: «задоволення від тексту», тобто афективну реакцію, і нейтральне науково-історичне читання в широкому

(c) О. Перепелиця, 2020

${ }^{1}$ Можна назвати кілька публікацій, виданих останніми роками, авторів деяких із них згадує і Лойд: Еріка Марті [Marty 2011], Мішеля Онфре [Onfray 2014], Натанії Меекер [Meeker 2014].

${ }^{2}$ Посилання на рецензовану книгу тут і надалі містять номер відповідної сторінки в круглих дужках, якому передує скорочення р. Ім'я автора і рік не наводяться.

${ }^{3}$ Хоча я би додав ще розлогу передмову Наталії Загурської до російськомовного перекладу листування Сада [Загурская 2004] і свої дві публікації в Sententiae [Перепелиця 2016а; 2016b]. 
критичному контексті. Цей підхід визначається автором в чисто «англофонному режимі інтелектуального дослідження», як контекстуальна інтелектуальна історія, що полягає в переміщенні тексту зі сфери літератури у сферу історії філософії (p. хіiі). Тож ідеться про Сада саме як про філософа, ба навіть про «ретельну контекстуальну реконструкцію» філософської «системи» Сада. Можливо, саме такий намір і вимагає від Лойда залучати суто філософські джерела, оминаючи, як на мене, важливий і доволі добре опрацьований контекст лібертенської літератури, аж ніяк не позбавленої філософських меседжів.

Відтак проблема полягає в тому, як узгодити філософію Сада зі загальними темами часу, до якого він належав (р. 3). Лойд презентує кілька контекстів, навіть традицій, в яких актуалізувався Сад (як філософ просвітницького гуманізму, як героїчний митець сюрреалізму, як легендарний революціонер), але формує власний дослідницький контекст, пропонуючи виходити не лише з філософського матеріалізму чи атеїзму Сада, адже «для контекстуальної інтелектуальної історії насправді $є$ більш значущі аспекти» (р. 13). Зокрема, він стверджує, що два «абсолютно важливі для розуміння його проєкту» аспекти, жоден 3 яких не може бути зведений до матеріалізму, $є$ такими: по-перше, це дискурс чутливості, який об'єднав елементи «радикального Просвітництва» 3 його більш консервативними елементами, по-друге, це моральна філософія XVIII століття (р. 13).

Звісно, віднесення Сада до Просвітництва є доволі проблематичним. Скажімо, Мiшель Онфре зауважує, що Сад - радше людина Старого режиму [Onfray 2014]. Загалом фігура Сада загострює тлумачення Просвітництва, дозволяючи відмовитися від певного упередження щодо загальності й уніфікованості Просвітництва як Проєкту. Власне, і я виходжу з тієї позиції, що доречно казати про низку просвітницьких проєкцій, тобто принципову множину (перетинів) медіацій просвітництва, тому мені видається виваженою й обгрунтованою думка Лойда, що полягає у відмові від спрощеного уявлення про Просвітництво як метанаратив раціоналізму й гуманізму в сучасному їх розумінні; власне, це підтверджується посиланням на Александера Кука, згідно з яким «просвітницьку концепцію “людства” найкраще розуміти не як загальне інтелектуальне припущення», а як «поле конфлікту, в якому мобілізуються конкурентні між собою візії людського життя й політичної організації» [Cook 2014]. I перша плюралізація Просвітництва, з якої виходить Лойд, це роз'єднання просвітницького Гуманізму на два основні напрями: «науки про людину» як філософський/науковий проєкт і гуманізм як моральний/політичний проєкт (р. 15). Важливо й те, що Лойд, попри відому форму Садової мови, стверджує, що не слід відкидати значення Сада для досліджень Просвітництва, як, прикладом, зробив відомий дослідник історії Просвітництва Пітер Гей, який заявив, що Сад «був не спадкоємцем, а карикатурою філософів» [Gay 1971: 285]. Лойд називає такий підхід «інтелектуально лінивим» i, зрештою, намагається продемонструвати, що «насправді в садівському творі $\epsilon$ дуже високий ступінь філософської витонченості» (р. 217).

Таким чином, головне намагання Лойда (можливо, наразі й викликане англомовною академічною традицією): спробувати включити Сада саме в історію філософії або, як він зауважує, створити проєкт ревізіоністської інтелектуальної історії. На мою думку, тут ідеться навіть про дещо більше - про статус і форму філософського дискурсу, а затим і про місце філософії в академічному середовищі ${ }^{4}$. Власне Лойд, дискутуючи з Вілом МакМорраном, Філіпом Роджером, Люсьєном Фрап’є-Мазур, Філіпом Солерсом,

${ }^{4}$ До речі, це те, із чим стикається творчий дисертант-філософ, коли читає вимоги до академічної побудови тексту, особливо, коли він привчився до філософії через Піррона, Монтеня, Ніцше, чи того таки Сада. 
нагадує про існування проблеми пародійності, множинності, фантастичності, іронічності, гумористичності Садових творів, яка подекуди заважає вважати Сада філософомсистематиком, бо нібито унеможливлює достовірне виявлення його власної позиції. Урешті-решт, це формує певну, що виходить з Ролана Барта (до неї дотичний і Марсель Енаф [Hénaff 1999]) традицію маркувати Сада як скриптора, що оперує мовою насильства чи насильством над мовою (р. 30$)^{5}$.

Зрештою, тут ми стикаємося також із принциповим питанням для розуміння філософії - питанням форми і змісту, перцептивного і концептуального. Бо чи має ефект читання, навіть афектація читанням, відігравати роль у викладенні філософської думки? Лойд не виключає всіх ефектів мови, навіть понад те - стверджує, що вони мають значення саме для викладення «системи» Сада, до якої намагається ставитися серйозно ${ }^{6}$. Але це значить ставитися серйозно й до Сада, не зводячи його до поезії чи клініки. Дослідження «системи» дозволяє представити Сада як філософа Просвітництва, який (на противагу популярному маркуванню його як філософа ірраціонального) суто на підставах просвітницького розуму розгортає систематичну критику моральної філософії свого часу. І таким чином «для Сада філософія є союзником бажання», а філософська критика дозволяє здійснитися його літературно-порнографічному проєктові (р. 35).

Якщо Сад включається до історії філософії, тоді саме відтворення й систематизація його філософії, ба навіть філософської системи, $є$ принциповим завданням дослідження. Як Лойд пропонує розуміти «систему» ${ }^{7}$ Сада? По-перше, він визначає кілька ії складових: теорію трансмутаційного матеріалізму, теорію природного права, моральну теорію і філософську антропологію, яка є визначальною й постає як дискурс чутливості, у центрі якого розміщено «тіло чутливості» (the body of sensibility) разом із тим, що він називає колапсом бінарності задоволення/болю (р. 23). Таким чином, дискурс Сада контекстуально розширюється до того, що Лойд називає редукціоністським (можна було б сказати й нестрогим чи навіть скептичним) матеріалізмом.

Наступне, що видається очевидним для будь-кого, хто включає Сада до сонму філософів, це злиття в Садовому тексті літератури й філософії, зрештою, це філософський роман, який Просвітництво винайшло як форму презентації своїх найрадикальніших ідей і найсміливіших мрій. Лойд виокремлює три складові Садового роману, що становлять філософсько-літературну «систему»: 1) так звана естетика огидного чи відразливого (aesthetics of the abhorrent) як літературна за формою контроверза теорії морального почуття, що виходить зі споріднення почуття добра з почуттям прекрасного; 2) проблема іншого, зокрема проблема лібертенської товариськості (libertine sociability), яка висновується з критики моральної філософії й постає як певний двигун Садового наративу; 3) літературні елементи використовуються для дистанціювання від філософських промов персонажів роману (р. 26).

${ }^{5}$ Ще однією $з$ принципових позицій Лойда є намагання вийти за межі, так би мовити, белетристичного, винятково естетичного пошанування Сада, відкидаючи моральний бік його творів. Натомість Лойд пише: «Якщо Сад створив традицію в сучасному мистецтві, яка продовжує естетизувати огиду, він зробив це не заради чистого мистецтва задля мистецтва, а заради проєкту, в якому естетичне і моральне були нероздільними. Важливо, що моральні наслідки цієї новації були або забуті, або проігноровані» (р. 164).

6 Так, Лойд цілком слушно стверджує, що сполучення філософії й порнографії є необхідним для діï текстів Сада. Ідеться про те, що в Сада «філософія фізично рухає або стимулює тіло» (р. 131). Зрештою, як і в Русо, ідеться про «базову образну [figurative] структуру»: «філософське висловлювання викликає афективну реакцію, філософія впливає на чутливість слухача, і саме це відзначає силу, правильність мовлення» (р. 133).

${ }^{7}$ Він наголошує, що пише це слово в лапках навмисно, задля дистанціювання від надміру обтяженого стереотипами визначення Садової спадщини. 
Реконструкція «системи» Сада розгортається в кілька етапів: спочатку окреслюється інтелектуальний і філософський (зокрема онтологія й епістемологія) контекст твору Сада 3 позицій дискурсу чутливості й тіла чутливості, разом із поясненням пріоритетності жанру філософського роману; потім розкривається моральна філософія епохи й реакція Сада щодо неї, яка синтезується передовсім на матеріалі найбільш зрілої, на думку Лойда, книги Сада «Історії Жульєти»; потім аналізуються оригінальні теорія тілесної чутливості (theory of corporeal sensibility) і теорія афективного саморозвитку чи самовдосконалення (theory of affective self-cultivation) Сада, що складають його філософський аскезис. Нарешті, автор завершує свій розгляд «системи» Сада, демонструючи іiі в контексті розвитку сучасної філософії, аналізуючи способи ії розгортання в так званій «континентальній» філософії і критичній теорії.

Коротко зупинюся на кількох найважливіших аспектах праці Лойда. Відтворюючи історичний контекст, він стверджує, що порнографія (хай би що ми казали, принаймні найгучніші садівські твори на загал такими й виглядають) Сада виходить із особливого розуміння тілесності XVIII століття, де тіло (тілесна чутливість) постає як центральний об'єкт пізнання, який у книзі розглядається в широкому контексті модерної епістемології, коли поставлено під сумнів відоме розрізнення між «британським емпіризмом» $\mathrm{i}$ «континентальним раціоналізмом». Адже для дискурсу чутливості XVIII століття більш значущими були неомеханіцизм і віталізм, а визначальним дискурсом (як засвідчувала Енциклопедія) була медицина (р. 52) ${ }^{8}$. 3 іншого боку, в історико-філософському сенсі праця Лойда демонструє принциповий розрив між сенсуалізмом Джона Лока і французьким Просвітництвом. Через ретельні посилання на Анрі Фуке й Антуана Ле Камю він показує, що «категорія чутливості урізноманітнюється» й, найголовніше, ідеться про розмаїття людських почуттів, що можуть радувати одного й не задовольнятимуть іншого (р. 64). Таким чином, саме почуття/відчуття (іхня розмаїтість) становить дискурс епістемології Просвітництва ${ }^{9}$, у межах якої співіснують раціональний і емпіричний суб'єкти (р. 65) ${ }^{10}$.

Чутливість, відчуття відкривають шлях і до нової моделі пізнання - спостереження (observation), що характеризує разом епістемологію, етику й естетику Просвітництва і презентоване фігурами генія-спостерігача (observer-genius) або науковця-спостерігача. Цей епістемологічний кут зору на світ, за Лойдом, $є$ загальною рисою епохи, що не визнає різниці між спостерігачем фізичних явищ чи лікарем і моралістом, тобто спостерігачем моральних явищ (р. 74). Хай там як, а ця «епістемологічна парадигма» (сказати б, епістемологічний метанаратив), не в сучасному доволі вузькому розумінні, була частиною «значно ширшої медико-філософської антропології» (р. 75). До того ж, важливо, що цей просвітницький дискурс чуттєвості «поєднав щонайменше три жанри, які сьо-

8 Віддамо належне Лойдові, він тут посилається на праці Ен Віли, яка доволі грунтовно опрацювала концепт чутливості в контексті медичного дискурсу [Villa 1998], і Армель Сен-Мартен, яка дослідила власне медичну обізнаність Сада і вплив медичного дискурсу на його творчість [St-Martin 2010].

9 Лойд справді відтворює доволі широкий історичний контекст, звертаючи увагу на концептуальну спорідненість, принаймні співзвучність різних дискурсів. І щонайперше це стосується чутливості. Окрім епістемалогічного віталізму, він звертає увагу на сентиментальний роман і на доволі розгалужений ужиток термінів «сентиментальний» і власне «sentiment» (p. 92).

10 Показовим є посилання на Ле Камю, за яким навіть спільність задоволення й болю не позбавляє від різних міркувань й ідей щодо них, що підкріплюється аргументом: «Сам Бог є здійснювальною причиною [efficient cause] наших ідей, бо тільки Він здатний сам створювати рух і діяти на розум і на тіла; але Бог лише збуджує ідеї в наших душах згідно з налаштуваннями [dispositions] наших тіл: таким чином, налаштування наших тіл є випадковими причинами наших ідей» [Le Camus 1769: 93]. Ба більше, за Фуке, те що людина має більший рівень інтелекту, порівняно з іншими тваринами, $\epsilon$ ефектом не раціональної душі, а вищої міри чутливості [Fouquet 1765: 15, 46] (p. 66-67). 
годні, як правило, вважаються окремими й, згідно з дисциплінарними межами в сучасному університеті, самостійними напрямами наукових досліджень: література, раціоналістична метафізика / спекулятивна натурфілософія й емпірична наука / експериментальна природна філософія і природознавство». Саме цей дискурс поєднав разом таких різних мислителів, як Сад і Русо (р. 75).

Слід звернути увагу, що Лойд, як представник англомовної філософської традиції, постійно зауважує, що філософський роман $є$ маргінальним жанром, але наполягає, що Сада слід розглядати в контексті традиції філософського роману, переважно як співрозмовника й опонента Русо (р. 99). Посилаючись на «Трактат про відчуття» Етьєна Боно де Кондильяка [Condillac 1970], він стверджує, що методологією філософського роману Просвітництва $\epsilon$ «уявне спостереження» [imagined observation], приклад якого: «уявити себе на місці людини-статуї і звідти спостерігати за дією власних почуттів» (р. 97), тобто уявити себе предметом власного спостереження. Тож дія методу Кондильяка, як і філософського роману, полягає у своєрідному втіленні знання в читачеві: «Важливим $є$ те, що фантастичні події, зображені в текстах, убачаються чи спостерігаються як “достовіpнi” [credible] або “правдоподібні” [plausible], коли читач уявляє їх» (p. 102). Зрештою, з підходом Лойда можна погодитися: Сад постає не просто порнографом (чи матеріалістом), його позиція (як і позиція Русо) є моральною, при цьому відтворює епістемологію Кондильяка, використовуючи художню літературу як «аналітичну техніку» (р. 102).

Ще слід звернути увагу на одне важливе посилання на «Теорію приємних почуттів» (1736), яка кілька разів перевидавалася протягом XVIII століття, вже забутого філософа Луї-Жана Левека де Пуї, теорія якого виходить із «сенсуалістського припущення, дуже поширеного в той період», ніби нас «тягне до речей, приємних [pleasant] нам, і відражає від неприємних [unpleasant]» ${ }^{11}$. Звідси виводиться «закон природи»: у світі все організоване таким чином, що приємним є вигідне нам i, навпаки, що шкідливе завдає болю. Таким чином, «теорія почуттів і моральна теологія різними шляхами досягають однієї й тієї ж мети» [Lévesque de Pouilly 1747: 12-14] (p. 118). У цій площині перетинаються етичне й естетичне. Загалом просвітницька теорія чутливості рухається між визнанням примату, з одного боку, приємних (передовсім естетично забарвлених) почуттів, симпатії i, з іншого боку, - суспільно значущого співчуття (жалю). А сам перехід до орієнтації на моральне почуття розглядається в контексті переходу від відчуття тіла й розуму до відчуття серця. Саме це є важливим для просвітницького сентименталізму ${ }^{12}$.

Концептуальним є розгляд Русо й Сада через розрізнення, відповідно, серця, що знає (Knowing Heart), і тіла, що знає (Knowing Body). Цьому розрізненню присвячено шостий розділ книги. Дискурсові серця (з усім моральним тягарем, присутнім у ньому), Сад відповідає дискурсом голови (tête) в такий спосіб, що, по-перше, принижує значення бінарності задоволення/болю, замінюючи їі «епістемологією інтенсивності» й таким чином руйнуючи сенсуалістську теорію морального почуття, взоровану на вчення

11 До речі, це корелює 3 думкою Клода Адріана Гельвеція, трактат якого був у бібліотеці Сада. Якщо висловлюватися більш пізньою філософською мовою, ідеться про прагматистсько-утілітаристську спрямованість, що стає помітною при розгляді Гельвецієм пристрастей і складає його «соціальну епістемологію», згідно з якою «кожна людина оцінює речі й особистостей за приємним чи неприємним враженням, яке вона отримує від них» [Helvétius 1758: 46] (p. 84).

12 Логіка аргументів лишається тією ж: «є приємність [agrément], пов’язана з рухами серця, коли воно не охоплене ненавистю чи страхом. Саме через рухи любові й ненависті ми прив'язуємося до того, що вважаємо добрим, одночасно відкидаючи те, що здається поганим. I так любов i ненависть - тобто пристрасті [passions] - розташовані в рухах серця [movements of the heart]». Так само як надія, бажання, дружба, подяка, щедрість і доброзичливість - це приємні відчуття; відтак доброзичлива людина для Пуї (і Русо), природно, є щасливою [Lévesque de Pouilly 1747: 49-56] (р. 126). Все це Лойд також пов'язує зі своєрідним просвітницьким епікуреїзмом. 
Пуї/Русо; i, по-друге, стверджує, що серце обманює нас, коли промовляє про мораль (р. 135). Важливо відзначити, що саме з позиції відтворення контексту Лойдові вдається включити Сада в історичний ланцюг філософії Просвітництва (Фуке, Пуї, Русо, Кондильяк, Гольбах, Дідро), коли Сад $є$ не просто контроверзою, а ймовірним логічним завершенням сенсуалістичного емпіризму («філософської традиції, яка майже завжди надавала епістемологічну першість почуттю» (р. 137)). Сад, зрештою, на думку Лойда, лише додає «сексуальне тіло, яке, з точки зору дотику, є найчутливішим», проте зазначає, що навіть ідея інтенсивності відчуття болю присутня вже в Кондильяка, який зауважує, що при дотику об’єкт (статуя) інтенсивніше відчуває біль, ніж за будь-яких інших відчуттів (р. 137). Певною мірою Сад лишень перевертає звичайну логіку, згідно з якою задоволення може перетворитися на біль. Дивним і новим є зворотне: біль може стати насолодою, а підгрунтям цього ствердження $\epsilon$ «принцип інтенсивності відчуття» (p. 138), який до того ж майже цілком викладається Садом в термінах Гольбаха (р. 140).

Три розділи (восьмий, дев'ятий і десятий) Лойд присвятив контекстуальному тлумаченню філософії природного права. Сад розглядається ним як співрозмовник і критик модерної традиції природного права, який переосмислює модель суспільної угоди й ідею єдиного принципу природи, властиву Томасові Гобсові й Жан-Жакові Русо. При цьому Сад презентує власну «ідіосинкратичну позитивну версію законів природи», спираючись, за Лойдом, на гобсівсько-русоїстську описову науку (descriptive science) про природу людини, і ба більше, певною мірою знову запроваджуючи спекулятивну метафізику/теологію, «намагаючись посилити своє бачення граничного авторитету природи» (р. 170). Відтак Лойд розглядає Садів проєкт дослідження істини людської природи в контексті намагань створити «систематичну нормативну теорію поведінки за моделлю, подібною до теорії сучасної науки», що, на противагу моральній філософії, шукала універсальні закони людської поведінки.

Суттєва, за Лойдом, відмінність Сада від усієї традиції суспільної угоди (і від Гобса, i від Русо) полягає в тому, що він не визнає типову кореляцію між приватним інтересом і можливостями суспільного щастя. Він розробляє поняття тимчасового спільного інтересу, але без відчуження індивідуальних прав на користь загальної волі (р. 184). Союзи Садових злочинців утворюються таким чином, аби приватний інтерес кожного з них зберігався. Це доволі умовна угода, адже ніхто не відмовляється від егоїзму. Саме тут є принциповою різниця між Гобсом, Русо і Садом щодо «імпульсів природи»: «для Гобса два основні природні імпульси - це людська жадібність і постулат природного розуму, згідно 3 яким «кожна людина прагне уникнути насильницької смерті», для Русо - це самозбереження й емпатія. Натомість для Сада є лише одна аксіома: власний інтерес (p. 193, 195). Сад відмовляється від основного принципу суспільної угоди - враховувати (бажання) Іншого, не вчиняти щодо інших того, чого б не бажав собі. На думку Сада, єдине призначення природи - давати задоволення нам, байдуже якою ціною й за чий рахунок.

Із цим узгоджується Садова переоцінка гобсівського вчення, згідно з якою прадавній стан війни виглядає «нескінченно кращим» за громадянське суспільство, «оскільки він надавав кожному вільне здійснення своїх сил і своєї вправності, чого кожний був позбавлений несправедливим пактом суспільства, яке завжди забирає занадто багато в одного й ніколи не дає достатньо іншому», тому кожен може стати сильнішим, порушуючи пакт; «і якщо закони повернуть його до того класу, з якого він хотів вийти, найгірше, що він втратить, - своє життя, що є нескінченно меншим нещастям, ніж існування в ганьбі [opprobre] та злиденності». Звідси висновується лібертенський (сказати б, із натяком на Гегеля, контрдіалектичний) принцип Сада: «Отже, це дві позиції для нас: або 
злочин, який робить нас щасливим, або ешафот, який перешкоджає нам бути нещасними» [Sade 1995: 165-166] (p. 190).

Із цим прямо пов'язана і правова модель Сада, яка, за Лойдом, грунтується на апології злочину, руйнування і, зокрема, вбивства. На думку Лойда, хоча Садова версія природи в цілому «базується на тому, що можна назвати трансформаційним матеріалізмом Гольбаха» (р. 210), Сад відхиляється від цього матеріалізму, адже йому йдеться про те, що природа бездумно «викинула» нас, і ми не маємо жодних зобов'язань перед нею. Відтак Сад створює своєю «системою» новий дуалізм, відокремлюючи від «природи» три царини (тварини, рослини, мінерали), що механістично відтворюють і руйнують себе за власними законами, такими, як метемпсихоз, варіації й одвічні мутації. «Цей новий дуалізм підтримує ідею розмежування між “природою” і “творенням”, тобто там, де раніше діяла бінарність природи/культури, пропонується бінарність людини/природи як творіння/творця. І вже з цього виводиться апологія злочину/деструктивності як «нормативно-моральний принцип»: коли ми знищуємо, ми робимо добре щодо природи, тому що ми повертаємо їй iii творчий потенціал, задовольняючи іiї (р. 213).

Близькою власне мені є інтерпретація Сада (принаймні історії Жульєти) у фукіанських термінах: роман - це історія етичного само-моделювання Жульєти на кшталт «турботи про себе», а філософія Сада в іiї засадах - це філософський аскезис, бо Сад, дотримуючись історичного контексту, розуміє це само-моделювання як тренінг чутливості (р. $232)^{13}$. Лойд дотримується відтвореного ним контексту і виокремлює три методологічні аспекти лібертенської практики самоплекання (self-cultivation): 1) процес дотримання вказівок старшого лібертена (senior libertine) особливо щодо побудови порнографічних сцен; 2) ключова техніка - постійне повторення лібертенських актів; 3) принципова роль виображення. Потім Лойд виокремлює кілька етапів такого аскезису: 1) усунення морального почуття чи совісті (це парафія філософії й наслідок зрілості, сказати б повноліття, яке дозволяє відмовитися від забобонів моралі й діяти холоднокровно, із абсолютною апатією); 2) подолання відрази до такої лібертенської поведінки, як поїдання лайна або канібалізм, що дозволяє дійти до витончених тортур ${ }^{14}$; 3) виховування апатії

13 Загалом це стосується загального освітянського аспекту, на який звертає увагу Лойд, адже твори Сада насичені саме дидактикою - це постійний безперервний процес виховання певних лібертенських «чеснот». Звісно, це також добре досліджений сюжет, хоча контекстуальні й концептуальні рішення Лойда також оригінальні. Рухаючись від громадянських пропозицій Пуї до Русо, щодо останнього він пише: його «Еміль» - «розширена медитація щодо способів, за допомогою яких органічну чутливість можна й потрібно тренувати, аби суб'єкт домігся дбайливо виплеканого природного спокою серед метушні громадянського суспільства» (р. 158). 3 іншого боку, Лойд звертає увагу й на «темпераментний детермінізм» Садової «системи», який висловлює лібертен Клервіль: «Ця суто фізична чутливість залежить від форми наших органів, делікатності наших органів чуття i, насамперед, від природи нервової рідини, в якій, як правило, я розміщую всі пристрасті людини». Освіта, звички, егоїзм лишень певним чином дозволяють здійснювати вроджену чутливість, яка спонукає до того чи іншого вибору» [Sade 1998a: 421-422] (р. 233). Хтозна, можливо, це поєднання природного детермінізму, аскезису й едукаціонізму є певною гібридизацією актуальних світоглядних віянь XVIII століття, адже тут можна впізнати і єзуїтські, і протестантські, і власне просвітницькі аспекти.

14 Прикметним, на думку Лойда, у філософському романі Сада $\epsilon$ те, що в одному творі міститься як естетизація огидного, так і філософська естетика, яка теоретизує його. Цим Сад одночасно досягає кількох важливих речей: 1) демонструє, що нас може тягнути до неприємних, навіть відразливих речей, чим порушує типову просвітницьку думку, що нас тягне до приємних і відштовхує від неприємних речей; 2) не заперечує існування краси й їі афективної привабливості, але присутність краси передовсім надихає лібертенів на акти ії руйнування і деформації; 3) естетика огидного стосується не лише насильства, але й перекрученого витонченого гастрономічного смаку (лайно, блювота, канібалізм); 4) використання гіперболи як риторичний екстремізм, який $\epsilon$ не антифілософським, а важливим аспектом шок-філософії (р. 161-162). 
(Сад пов'язує ії з особливим стоїцизмом), насамперед, прагматичної й інструментальної; 4) моральна нечутливість поповнюється фізичною нечутливістю; 5) досягнення достатньої майстерності для розгортання власного виображення ${ }^{15}$, аби вже не керуватися вказівками інших лібертенів (р. 236).

Остання частина книги «Висновок» має доволі гучну назву «Проти Діалектики Просвітництва, або як не читати Канта із Садом» і натякає одразу на дві найвідоміші інтерпретації Сада в контексті просвітницьких проєкцій континентальної філософії і критичної теорії, зокрема Теодора Адорно / Макса Горкгаймера і від Жака Лакана до Славоя Жижека ${ }^{16}$. Лойд закидає Адорно і Горкгаймеру, що ті у своїй надто лінійній і спрощеній схемі діалектики Просвітництва поєднують Канта, Сада й Ніцше як критиків певного виду моральної сентиментальності, ігноруючи різницю між ними, зокрема й щодо мети їхніх критичних підходів до моральності чутливості (р. 290). Прикладом, Лойд відзначає, що кантівська теорія суб'єкта цілком не відповідає суб'єктові чутливості французького Просвітництва, а щодо Ніцшевої концепції «gift-giving virtuе» годі вже й казати про ії принципову відмінність від намірів Сада.

Зрештою, пише Лойд, Сад $є$ «тонким барометром моральної філософії [своєі] епохи», але також іiї систематичним критиком. «Трактувати Сада як симптом - не кажучи вже як визначальний симптом - Просвітництва в цілому, значить не розуміти цього», адже, як доводить Лойд, Садова «літературне й порнографічне виображення просто не може бути виправдане моральною філософією Просвітництва» й, «напевно, ніхто не зрозумів цього краще за Сада» (р. 293).

Нарешті, Сад завжди викликає думки про можливе й неможливе, але перевагою книги Лойда $є$ те, що в ній реконструюється Сад свого часу, контекстуальний Сад, а не Сад наших власних проєкцій і припущень, живий Сад. Проте дуже часто, ось як і в нашому академічному полі, ідеться не про зміст, а лишень про форму, не стільки про метод дослідження, скільки про спосіб репрезентації. Сад намагався реабілітувати злочин у, так би мовити, злочинний спосіб, забороненою мовою, а тому відкидався науковою спільнотою на маргінес. Книга Лойда є академічним дослідженням, йому вдалося не підпасти під вплив Садової форми/мови, але показати за нею систему (нехай і в лапках). Проте для нас лишається питання не стільки, що робити зі Садом, скільки, що робити із собою. Тобто Сада можна й потрібно читати академічно як одного з представників історії філософії, але чи можна писати як Сад? Не в сенсі порнографії, звісно, а в сенсі цілковитого звільнення від будь яких суспільних умовностей? Як загалом узгоджуються чисто епістемологічна позиція й белетристична іiі репрезентація?

Міркуючи над постаттю Сада, я би вбачав у ньому не «героїчного бога» радикальних модерністів на кшталт сюрреалістів першої половини XX століття і навіть не маргінального просвітника чи революціонера, а радше постмодерністську (уже також напівзабуту) фігуру - дивовижну трансгресивну пародійну контамінацію всього на світі: філософії, науки, белетристики, порнографії, витонченості й поганого смаку і насамкінець не забути б - садизму. Його успіх наприкінці XX століття й до сьогодні полягає в тому, що він відбиває й нашу символічну реальність, і наше уявне, і наше реальне бажання.

15 Зауважимо, що Лойд відзначає дедалі більшу важливість виображення в просвітницькому дискурсі чутливості, адже саме воно необхідне для порівняння того, що існує, і того, що не існує, для складання суджень, які є лише відчуттями чи почуттями (р. 87-88). Тому, за Гельвецієм, «судження виробляється на основі образу, якому надає перевагу той, хто виобрахує, сцени, яка найбільш сприятливо збуджує їх чутливість» (р. 88).

16 Принагідно зверну увагу, що актуальність лаканіанського дискурсу про Сада (насправді ігнорованого Лойдом) засвідчує дослідження Дені Нобуса «Закон бажання» [Nobus 2017]. 
Написати мовою арго науковий трактат, чи нескінченно повторювати смс-ками непристойні натяки - це мистецтво вже опановане Садом. Але академічне дослідження Сада в просвітницькому контексті закидає нам проблему місця Сада з усім його контекстом як проблему долі Просвітництва сьогодні. Така ревізіоністсько-контекстуальна реконструкція «системи» Сада, зокрема трансформації просвітницьких сенсуалістичного емпіризму, моральної філософії і природного права, може стати в пригоді для їхньої реактуалізації щодо (пост)сучасності, особливо коли дивитися на неї крізь призму об'єкторієнтованої онтології.

P.S. Хай би що хто казав стосовно аж надто сучасного характеру Садових ідей, стосовно садизму як чи не єдиної філософії, властивої сучасній добі, перевірки фактами ці твердження не витримують. Дивлячись на події, що відбуваються останнім часом, на наше так зване «голе життя» у світі глобальної біополітики (чи навіть вже постглобальної кіберполітики) з абсолютним приматом збереження життя за будь-яких умов, у будь-який спосіб і за будь-яку ціну, можна стверджувати, що парадоксальний «віталізм» Сада лишається геть маргінальним, адже його основним принципом є ентропійність насолоди, а відтак і можливість/припущення, навіть неодмінність болю і смерті, ще й поза будь-якою турботою про іншого.

Цілковитою контроверзою таким цінностям звучить один із прикінцевих діалогів «Філософії в будуарі». Коли Ежені міркує щодо необхідності вбити власну мати, архетиповий лібертен Дольмансе радить спочатку ії заразити страшною хворобою і розтлумачує парадоксальну логіку цього дійства: «Добре, друзі мої. Як ваш наставник, я пом’якшу вирок. Але відмінність, яка виявиться між моєю вимовою й тим, що вимагали ви, полягає в тому, що ваші присуди нагадують злі жарти, тоді як мій буде виконано. Я маю лакея з одним із найкращих членів, які лише можуть бути в природі. Та, на жаль, із нього сочиться вірус і його пожирає одна з найжахливіших форм сифілісу, яку десь ще бачили у світі. Я покличу його, і він впорсне свою отруту в обидва природні канали, які прикрашають цю милу і люб'язну даму. Тож поки триватимуть враження від цієї жорстокої хвороби, курва буде пам’ятати, що не можна турбувати дочку, коли та злягається. (Всі аплодують, вводять слугу). Дольмансе до лакея: Ляп'єрp, трахни [foutez] цю жінку. У неї надзвичайне здоров'я, і ця насолода, можливо, вилікує тебе - засіб [remède] не позбавлений значення прикладу» [Sade 1998b: 174]. Так і хотілося б завершити чимось на кшталт: усі сміються. Завіса.

\section{СПИСОК ЛІТЕРАТУРИ}

Загурская, Н. (2004). Эпистола из камеры vs. Философии в будуаре. In Д.-А.-Ф. де Сад, Письма вечного узника (с. 5-66). Москва: Эксмо.

Перепелиця, О. М. (2016а). Порно(у)топія маркіза де Сада: «Філософія в будуарі» vs «Бенкет». Sententiae. 34(1), 95-110. https://doi.org/10.22240/sent34.01.095

Перепелиця, О. М. (2016b). Буття і насолода: від суб'єкта cogito Декарта до суб'єкта imago де Сада. Sententiae, 35(2), 82-93. https://doi.org/10.22240/sent35.02.082

Сад, Д. А. Ф. де. (2016). Філософія в будуарі. Діалоги, призначені для навчання молодих дівчат. Київ: Комубук.

Condillac, E. B. de. (1970). Traité des sensations. In E. B. de Condillac, Oeuvres complètes (T. III, p. 1-327). Genève: Slatkine. 
Cook, A., Curthoys, N., \& Konishi, S. (2013). The Science and Politics of Humanity in the Eighteenth Century: An Introduction. In A. Cook, N. Curthoys, \& S. Konishi (Eds), Representing the Human in the Age of Enlightenment (p. 1-14). London: Pickering \& Chatto.

Fouquet, H. (1765). Sensibilité, Sentiment (Médecine). In D. Diderot, \& J. le R. D’Alembert (Eds.), Encyclopédie ou Dictionnaire raisonné des sciences, des arts et des métiers, par une Société de Gens de lettres (T. 15: pp. 38-52). Paris: Briasson, David, Le Breton \& Durand.

Gay, P. (1971). The Party of Humanity: Essays in the French Enlightenment. New York: Norton.

Helvétius, C. A. (1758). De L'Esprit. Paris: Durand.

Hénaff, M. (1999). Sade: The Invention of the Libertine Body. (X. Callahan, Trans.). Minneapolis: University of Minnesota Press.

Le Camus, A. (1769). Médecine de l'esprit. Paris: Chez Ganeau.

Lévesque de Pouilly, L.-J. (1747). Théorie des Sentimens Agréables. Genève: Barrillot \& Fils.

Marty, É. (2011). Pourquoi le XXe siècle a-t-il pris Sade au sérieux? Paris: Seuil.

Meeker, N. (2014). Sade at the End of the World. In K. Parker, \& N. Sclippa (Eds.), Sade's Sensibilities (p. 87-101). Lewisburg: Bucknell UP.

Nobus, D. (2017). The Law of Desire: On Lacan's 'Kant with Sade'. London: Palgrave Macmillan.

Onfray, M. (2014). La Passion de la méchanceté : sur un prétendu divin marquis. Paris: Autrement.

Sade, D. A. F. de. (1995). Justine ou les malheurs de la vertu. In D. A. F. de Sade, Oeuvres: Volume II (p. 120-390). Paris: Gallimard.

Sade, D. A. F. de. (1998a). Juliette ou les prospérités du vice. In D. A. F. de Sade, Oeuvres: Volume III (p. 179-1262). Paris: Gallimard.

Sade, D. A. F. de. (1998b). La Philosophie dans le boudoir, ou Les Instituteurs immoraux. In D. A. F. de Sade, Oeuvres: Volume III (p. 1-178). Paris: Gallimard.

St-Martin, A. (2010). De la médecine chez Sade: Disséquer la vie, narrer la mort. Paris: Champion.

Vila, A. C. (1998). Enlightenment and Pathology: Sensibility in the Literature and Medicine of EighteenthCentury France. London: Johns Hopkins UP.

Одержано 17.01.2020

\section{REFERENCES}

Condillac, E. B. de. (1970). Traité des sensations. In Oeuvres complètes (T. III, p. 1-327). Genève: Slatkine.

Cook, A., Curthoys, N., \& Konishi, S. (2013). The Science and Politics of Humanity in the Eighteenth Century: An Introduction. In A. Cook, N. Curthoys, \& S. Konishi (Eds), Representing the Human in the Age of Enlightenment (p. 1-14). London: Pickering \& Chatto.

Fouquet, H. (1765). Sensibilité, Sentiment (Médecine). In D. Diderot, \& J. le R. D’Alembert (Eds.), Encyclopédie ou Dictionnaire raisonné des sciences, des arts et des métiers, par une Société de Gens de lettres (T. 15: pp. 38-52). Paris: Briasson, David, Le Breton \& Durand.

Gay, P. (1971). The Party of Humanity: Essays in the French Enlightenment. New York: Norton.

Helvétius, C. A. (1758). De L'Esprit. Paris: Durand.

Hénaff, M. (1999). Sade: The Invention of the Libertine Body. (X. Callahan, Trans.). Minneapolis: University of Minnesota Press.

Le Camus, A. (1769). Médecine de l'esprit. Paris: Chez Ganeau.

Lévesque de Pouilly, L.-J. (1747). Théorie des Sentimens Agréables. Genève: Barrillot \& Fils.

Marty, É. (2011). Pourquoi le XXe siècle a-t-il pris Sade au sérieux? Paris: Seuil.

Meeker, N. (2014). Sade at the End of the World. In K. Parker, \& N. Sclippa (Eds.), Sade’s Sensibilities (p. 87-101). Lewisburg: Bucknell UP.

Nobus, D. (2017). The Law of Desire: On Lacan's 'Kant with Sade'. London: Palgrave Macmillan.

Onfray, M. (2014). La Passion de la méchanceté : sur un prétendu divin marquis. Paris: Autrement.

Perepelytsia, O. (2016a). Porno(u)topia of Marquis de Sade: "Philosophy in the Bedroom” vs "Symposium”. [In Ukrainian]. Sententiae, 34(1), 95-110. https://doi.org/10.22240/sent34.01.095

Perepelytsia, O. (2016b). Being and Enjoyment: from Descartes' Subject of Cogito to Sade's Subject of Imago. [In Ukrainian]. Sententiae, 34(2), 82-93. https://doi.org/10.22240/sent35.02.082

Sade, D. A. F. de. (1995). Justine ou les malheurs de la vertu. In D. A. F. de Sade, Oeuvres : Volume II (p. 120-390). Paris: Gallimard.

Sade, D. A. F. de. (1998a). Juliette ou les prospérités du vice. In D. A. F. de Sade, Oeuvres : Volume III (p. 179-1262). Paris: Gallimard. 
Sade, D. A. F. de. (1998b). La Philosophie dans le boudoir, ou Les Instituteurs immoraux. In D. A. F. de Sade, Oeuvres : Volume III (p. 1-178). Paris: Gallimard.

Sade, D. A. F. de. (2016). Philosophy in the Bedroom. Dialogues designed to educate young girls. [In Ukrainian]. Kyiv: Komubuk.

St-Martin, A. (2010). De la médecine chez Sade: Disséquer la vie, narrer la mort. Paris: Champion.

Vila, A. C. (1998). Enlightenment and Pathology: Sensibility in the Literature and Medicine of EighteenthCentury France. London: Johns Hopkins UP.

Zahurska, N. (2004) Epistola in Camera vs. Philosophy in the Bedroom. In D.-A.-F. de Sade, Letters of the Eternal Prisoner (p. 5-66). [In Russian]. Moscow: Eksmo.

Received 17.01.2020

\section{Oleh Perepelytsia}

Revisionist-contextual reconstruction Marquis de Sade's Philosophical “System”. Lloyd, H.M. (2018) Sade's Philosophical System in its Enlightenment Context. Saint Lucia: Springer International Publishing; Palgrave Macmillan.

The review identifies the components of contextual intellectual reconstruction Marquis de Sade's philosophical system in the context of the Enlightenment carried out by H. M. Lloyd. The fundamental importance of the enlightenment discourse of sensibility, its influence on the theory of natural law and moral philosophy of the Eighteenth Century is established. The main stages of reconstruction of Sade's "system" are demonstrated, namely: 1) philosophical context (ontology and epistemology) as a discourse of sensibility; 2) the specificity of the genre of the "roman philosophique"; 3) the moral philosophy of the era and the Sade's response to it; 4) the theory of corporeal sensibility and the theory of affective self-cultivation of Sade, that is, its philosophical askesis; 5) understanding of Sade in the context of the development of contemporary philosophy. It is noted that such reconstruction problematizes of the formal and substantive components of philosophical discourse in the academic environment.

\section{олег Перепелиця}

Ревізіоністсько-контекстуальна реконструкція філософської «системи» маркіза де Сада. Lloyd, H.M. (2018) Sade's Philosophical System in its Enlightenment Context. Saint Lucia: Springer International Publishing; Palgrave Macmillan.

В огляді визначено складові контекстуальної інтелектуальної реконструкції філософської системи маркіза де Сада в контексті Просвітництва, здійсненої Г. М. Лойдом. Встановлено принципове значення просвітницького дискурсу чутливості, його вплив на теорію природного права й моральної філософії XVIII століття. Продемонстровано основні етапи реконструкції «системи» Сада, а саме: 1) філософський контекст (онтологія й епістемологія) як дискурс чутливості; 2) специфіка жанру філософського роману; 3) моральна філософія епохи та реакція Сада щодо неї; 4) теорія тілесної чутливості та теорія афективного саморозвитку Сада, тобто його філософський аскезис; 5) особливості розуміння Сада в контексті розвитку сучасної філософії. Зазначено, що така реконструкція проблематизує формальні й змістовні складові філософського дискурсу в академічному середовищі.

Oleh Perepelytsia, D.Sc. (Philosophy), Head of the Department, V. N. Karazin Kharkiv National University.

Олег Перепелиця, д. філос. н., завідувач кафедри, Харківський національний університет імені В. Н. Каразіна.

e-mail: o.perepelytsia@karazin.ua 